\title{
Success of Resettlement and Rehabilitation Activity Amidst Obstacles: A Study of China
}

\author{
Neelmani Jaysawal \\ Department of Social Work, Visva-Bharati \\ *Corresponding Author: neelmanijayswal@gmail.com
}

\begin{abstract}
Rehabilitation and Resettlement(R \& R) is a model of development which enforces certain technical and economic options before masses. The success of any developmental programme cannot be judged in merely their effect on income and employment opportunities but more specifically on welfare of displaced people through their participation in decision making process of development project and proper resettlement. Therefore, the major question which arises here is 'what is successful resettlement and rehabilitation programme'. In the discourse of rehabilitation and resettlement programme, there are two distinct processes: the first, resettlement, is a one-time event of physical relocation. The second, rehabilitation, is a long-time process that involves rebuilding people's physical and economic livelihood, their assets, their cultural and social links, and psychological acceptance of the changed situation. Rehabilitation is a process needed by both the Displaced People and the Project Affected Persons, and it must begin long before physical displacement or deprivation (Fernandes, Walter). Having perception of all these prerequisites of a successful resettlement and rehabilitation program, the World Bank has played a very pivotal role. In addition to its success, the R \& $\mathrm{R}$ programme faces lots of impediments also like forced displacement of masses to inappropriate habitations, involuntary displacement, and neglect of social, economic, cultural rights of displaced persons, absence of gender consideration in rehabilitation programme and lack of transparency in flow of information from project authority to displaced community. Therefore, this paper seeks to explore these impediments in the path of Resettlement and Rehabilitation programme and adoption of some good practices for ensuring successful R \& $R$ programme through review of R \& R programmes of some of its projects in China.
\end{abstract}

Keywords Resettlement and Rehabilitation, Displacement, Project Affected People, Inclusive Growth

\section{Introduction}

In the discourse of development paradigm, the notion of Copyright (C) 2013 Horizon Research Publishing
Resettlement and Rehabilitation(R \& R) keeps an important position. The terminology 'Displacement' which is seen as the result of a model of development that enforces certain technical and economic choices without giving any serious consideration to social cost, originates the essentiality for resettlement and rehabilitation. There are a very few chances that displaced people have been given any scope in their proper rehabilitation. The displacement literature bears testimony to traumatic forced and delayed relocation. Hence, rehabilitation has always been equated with physical relocation which stresses more on availability of physical amenities to masses than their inclusive adaptation to new milieu. Forced relocation usually results in people being transplanted from a social ecology in which they were primary actors to one in which they are aliens; they are not only very vulnerable but also end up in most cases as an underclass in their new socio-cultural milieu (WCD Thematic Review, 2000). Cernea identifies certain risks related to resettlement and rehabilitation as landlessness, joblessness, homelessness, marginalisation, increased morbidity and mortality, food insecurity, loss of access to common property and services, and social disarticulation (ibid).

Therefore, the major question which arises here is "what is successful resettlement and rehabilitation programme'. As envisaged, development-induced displacement and resettlement in India focuses more on physical amenities' availability rather than social, cultural milieu for displaced people, this question always arises whether it is leading to empowerment of masses for inclusive growth or mere shifting of habitat from one place to another.

Therefore, it is imperative for us to know the meaning of resettlement and rehabilitation along with its success and impediments.

\section{Definition}

The World Bank states that Resettlement covers all economic, social losses resulting from land taking and restriction of access together with consequent compensatory and remedial measures. It further says that Resettlement includes (a) acquisition of land and physical structure on 
land (b) physical relocation (c) economic rehabilitation of displaced people to improve income and living standard (Involuntary Resettlement Sourcebook, World Bank, 2004).

The Oxford dictionary also provides a definition about Rehabilitation. According to it, "Rehabilitation is a course of treatment, largely physical therapy designed to reverse the debilitating effects of an injury."

Again, the World Health Organization, in its second report of expert committee defines social rehabilitation as "the part of the rehabilitation process aimed at the integration or reintegration of a disabled person into society by helping him to adjust to the demands of family, community, and occupation, while reducing any economic and social burdens that may impede the total rehabilitation process."

Therefore, the analysis of above-mentioned definition gives two broad dimensions of resettlement and rehabilitation. One is holistic view and another is narrow view.

The holistic view of $\mathrm{R} \& \mathrm{R}$ encompasses all sets of services and processes which allow the victim to gain independence and make use of his freedom. On the other hand, its narrow viewpoint stresses more on physical and psychological repatriation.

\section{Objectives of this Paper}

- This paper seeks to explore challenges in the path of Resettlement and Rehabilitation Activity.

- It intends to highlight shortcomings in the policy framework for eliminating improper resettlement.

- It aims at exploring some good practices which may make resettlement and rehabilitation activity successful.

\section{Methodology}

This paper is exploratory based on review of literature. It has included references of journal articles, books, Government reports, case-studies for getting inferences.

\section{Obstacles of Resettlement and Rehabilitation}

The Resettlement and Rehabilitation (R\&R) suffers from various obstacles caused by man-made factors and some natural entities. The current scenario of displacement has led to never-ending problem of inequitable resettlement of Project Affected people. Either in terms of dam construction, extraction of natural resources, establishment of some economic enterprises or infrastructure development, the poor and deprived people has not been repatriated properly.

All these issues pose obstacles in resettlement and rehabilitation which can be illustrated through following impediments

\section{Insufficient Consultation with Aggrieved Persons}

In India, the resettlement and rehabilitation is not substantiated with participation of aggrieved persons. Claims that local populations should be granted inalienable rights to their lands where state access is subject to a mutually defined process of negotiation are interpreted as 'sub-nationalist' or 'secessionist' and therefore, except in the rarest of rare cases, denounced (Kothari, Smitu, 1996).

Most of these displacement activities have been seen in the area of industrial and infrastructure development. In all these cases, the Project Affected People (PAP) has not been given any say while being rehabilitated. In the words of Michael Cernea, it is "a spiral of impoverishments". In other words, it may be called forced displacement where the choice is not available before the displaced people.

\section{Flawed Compensation to the Displaced People}

The compensation paid to the displaced people is also incongruent with real market value. The local authorities determine the value as per their pre-defined norms which actually depreciate the value of land. Apart from price, even the land given as part of compensation, is not habitable. The amenities available on rehabilitated land are not sufficient enough to live a decent life. Therefore, the displaced people get vulnerable to indebtedness for purchasing basic supplies needed for meeting their basic needs on new place. Even some of assets like trees are excluded from the list of payments to the displaced persons.

\section{Under-Funding of Resettlement and Rehabilitation Plan}

The Government's plan for Resettlement and Rehabilitation is having lacunae of under-funding. This occurs only when the respective project budget does not include the expected total cost of resettlement and rehabilitation. The replacement cost is not having provision of inflation if payments are delayed. Therefore, the interest accrued on current price is not given to the displaced person. Compensation amounts were determined at the time of preliminary notification of intent to acquire lands, whereas actual payment of compensation often lagged by several years, with the adequacy of compensation further eroded by inflation.

\section{Irregularities in Allocation}

The Rehabilitation and Resettlement activity is marred by continuous irregularities in allocation of assets to the displaced people. Some of the Project Affected People have not been allocated a single land and some of them are having allotments in the name of their extended family members. Even in case of displacement, there has been found some irregularities. Some Project Affected Person is being displaced by one project whereas he has already been displaced by either another agency or subsidiary unit of same agency. 


\section{Lack of Quality Control}

The resettlement and rehabilitation policy is lacking effective quality control mechanism which also poses a challenge in its efficacy. Although the builders have been provided enough land and construction materials by the government yet, the construction work at rehabilitated sites are of poor quality. Cracks in the walls, leakages and seepages are evidence of poor monitoring of the quality of construction, approvals and clearances for the same. The close nexus between builder and bureaucrat brings laxity in maintenance of quality-check on respective construction.

\section{Uninhabitable Condition of Rehabilitated Colonies}

The inhumane condition of newly built colonies for habitation of Project Affected Persons is also a blot on R \& R. These colonies have deficiency of civic amenities, employment opportunities, maladjustment with host community, health and hygiene concerns. The lack of estimation of new habitation's living conditions reduces the effectiveness of R \& R policy. Therefore, it has been found out that most of the people rehabilitated at new place shift to a newer place again as per their own comfort level. Whereas one finds Displaced Person from other social groups residing in the Mayurakshi resettlement colonies, not a single tribal family is to be found there, though more than half of the displaced were tribals (Mohammed, Asil, 2000).

\section{Monopoly of State and Project Officials}

The Resettlement and Rehabilitation program is very much dependent upon decisions taken by government and project officials. There is no scope for displaced persons to suggest measures for their resettlement. Questions like, where to resettle them, what measures need to be initiated to enhance the quality of life of the settlers, are decided by the resettlement officials (ibid). There is no social assessment which may give scope of appraisal of project in the hands of displaced persons. Whatever appraisal of a project is needed, is done by either government official or hired agency. In this way, the entire scenario of $R \& R$ is regulated by the state and legitimizes the monopoly of developmental agencies.

Having glimpse of above-mentioned impediments of Resettlement and Rehabilitation programme, it comes to our mind that rehabilitation is losing its actual meaning. Therefore, it is dire need of hour to visualize the essential good practices of R \& R so that it may act as it is meant for. Lets' see those pre-requisite good practices of $\mathrm{R} \& \mathrm{R}$ which shows its successful activity.

\section{Good Practices of Resettlement and Rehabilitation for Its Success}

As envisaged from already discussed impediments, resettlement is driven by force. The social and environmental cost has been abandoned in the wake of development. Therefore, there have been exemplified some essential good practices for R \& R which ensure reversal of situation faced by displaced people.

\section{Public Hearings and Reviews}

Public hearings and Reviews are widely used strategies in certain countries to enable people to participate in decision making process. The public hearing provides a scope for open discussion over various institutional, social, environmental aspects of any developmental project. The Public hearing brings transparency. Independent Reviews are most effective when they are conducted by organisations / people who enjoy a relatively high degree of credibility from all stakeholders and when the methodology of the review is participatory and transparent (ibid).

\section{Social Impact Assessment}

The assessment of any project from environmental and social points of view brings estimation of effect of project on aggrieved persons. It is imperative that there should be a detailed assessment of socio-economic conditions of the people who may be negatively affected. Again, the adoption of a comprehensive plan to mitigate these impacts and analysing extent of displacement, loss of livelihood is an important indicator of successful resettlement and rehabilitation program.

\section{Enabling People to be Beneficiaries}

Interestingly the idea is an old one, stretching in India as far back as 1902. When plans were drawn up for the Nira Canal System in western India, a detailed exchange of holdings in the command was worked out that could allow for the displaced to be resettled in the area (India Report, 1999). Allotting land in the command areas is the most definitive way of sharing the benefits of the project with the displaced persons. Several irrigation projects in India, particularly in Maharashtra and Madhya Pradesh, attempted to gain land in the command area for rehabilitation using various land reform measures (Land Ceiling Act, Maharashtra Resettlement Act 1976, Madhya Pradesh Resettlement Policy 1986).

\section{Defining Eligibility for Benefits of Resettlement and Development Programme for Negatively Affected Persons}

The inclusion of eligibility criteria has potential to benefit the actual displaced person. It is able to address the widespread impact of the diverse aspects of a developmental project upstream and downstream along with its host communities and negatively affected people. The World Bank has defined certain criteria over which the displaced persons may be identified and entitled for actual benefit. It states that persons who do not have formal legal rights to land and other assets, should be provided such claims 
through a process identified under $\mathrm{R} \& \mathrm{R}$ policy. If such persons have uninterrupted possession of the land for at least one year prior to the commencement of the census, they are entitled to resettlement assistance (WCD Thematic Review, 2000).

\section{Community Managed Resettlement}

Community managed resettlement is one of good practices of $\mathrm{R} \mathrm{\&} \mathrm{R}$ around the world. It does not mean mere community participation but community control and its ownership of resettlement programme. The more the resettlement programme is community and collective centred, the greater the chances of it succeeding. One of the examples in this affair may be quoted from hydroelectric project of ELETROSUL, a publicly owned power generation utility of Southern Brazil. In response to the 1979 announcement of ELETROSUL plans to build a series of dams in the Uruguay river basin in the States of Santa Catarina and Rio Grande do Sul, the communities that were to be affected responded by beginning a process of political organisation, facilitated by rural unions, church activists and sections of the academic community. They organised themselves into the Comissão Regional dos Atingidospor Barragens (CRAB). (ibid). This included the identification, purchase, and preparation of land, construction of houses, farm buildings and community buildings and access roads.

After perusal of above-mentioned good practices of this $\mathrm{R}$ \& R program, it comes to our mind that there are certain parameters over which trauma of displacement may be minimized. All these good practices could be visualized clearly through its application in some of global projects which are being illustrated through following case:-

\section{Illustration through Some Cases}

There are certain developmental projects around the world which negate the exploitative function of $R \& R$. The development projects of China have showcased the good practices of Resettlement and Rehabilitation.

\section{Developmental Projects of China}

In China, some projects are explicitly designed to improve housing standards following displacement. In the Shanghai Sewerage Project, most DPs expressed satisfaction with provisions that increased their rents but provided nearly double the housing space and included indoor kitchens and sanitation facilities.

Plans for the Second Shanghai Sewerage Project allowed DPs to choose between government apartments supplied on a rental basis or private apartments available at one-third of construction costs. Specialized training at technical schools, municipal vocational training centers, or training centers at large enterprises were provided. The training was linked to jobs already promised to the DPs.
Again another project, the Second Red Soils Area Development Project provided one permanent job per household in construction or in the agro-processing enterprise caused by displacement.

Then, Xiaolangdi Resettlement Project encouraged non-agricultural employment for some displaced farmers. To ensure sufficient employment to acquire skills, the project provided five-year job guarantees.

Again, consultations with people in areas to be affected by the Second Henan Provincial Highway Project led to the design of highway underpasses at regular intervals to restore access to divided lands, markets, or other facilities.

Liaoning Environment Project deposited some of its land compensation funds in the bank and distributed the annual interest to the elderly, students, and laborers in prorated shares.

The Plans for the Second National Highways Project included temporary acquisition of agricultural land for four years. Compensation for loss of access and cultivation was calculated as five times the average annual value of agricultural production.

\section{Conclusion}

The scenario of Resettlement and Rehabilitation signifies more than a mere physical relocation. The provision of compensation alone cannot justify the success of $\mathrm{R} \& \mathrm{R}$ programme. There is a need to evolve institutions to protect and strengthen the rights of individuals. It has felt the need to redefine the voluntary and involuntary resettlement. Sometimes, the voluntary resettlement leads to reversal of trend. The complicated provision of several individual projects brings illusion in proper rehabilitation. Apart from it, the programme of resettlement and rehabilitation needs to have gender perspective regarding its impact. As women are backbone of most of our household economy around the globe, the analysis of post-resettlement effect on their livelihood also gives a view whether $\mathrm{R} \& \mathrm{R}$ activities are pro-development or mere eyewash. There must be some safeguards to facilitate women full access and enjoyment of all project related compensation. There should not be any displacement until clear and full rehabilitation of individuals is done.

\section{REFERENCES}

Asil, Mohammed, 2000; Why Displaced persons reject Project Resettlement Colonies, Economic and Political Weekly, vol. 35, no. 24, http://www.jstor.org/stable/4409382 (accessed on 27-04-2013).

Bartolome, L.J., de Wet, C., Mander, H., Nagraj, V.K. 2000; Displacement, Resettlement,Rehabilitation, Reparation, and Development, WCD Thematic Review I.3,

http://siteresources.worldbank.org/INTINVRES/Resources/Displa 
ceResettleRehabilitationReparationDevFinal13main.pdf (accessed on 22-04-2013).

Cernea, Michael, M, 1999; Why Economic Analysis is essential to Resettlement-A Sociologist's view, Economic and Political Weekly, vol. 34, no.31, http://www.jstor.org/stable/4408255 (accessed on 27-04-2013).

Fernandes, Walter; India's Forced Displacement Policy and Practice, Is compensation upto its functions, http://onlineministries.creighton.edu/CollaborativeMinistry/NESR C/Walter/chp-7.pdf (accessed on 23-04-2013).

Involuntary Resettlement Sourcebook, Planning and Implementation in Development Projects, World Bank Report,http://www4.worldbank.org/afr/ssatp/Resources/HTML/Ge nderRG/Source $\% 20 \% 20$ documents $\% 5$ CTool $\% 20 \mathrm{Kits} \% 20 \& \% 20 \mathrm{G}$ uides $\% 5$ CDesigning\%20Projects/TLPRO10\%20invol\%20resettle mentsourcebookWB.pdf (accessed on 20-04-2013).

Kothari, Smilu, 1996; Whose Nation? The Displaced as Victims of Development, Economic and Political Weekly, vol. 31, no. 24, http://www.jstor.org/stable/4404269 (accessed on 27-04-2013).

Levitt, Joanna, 2007; The Need for New Approaches to Involuntary Resettlement: Lessons from Cambodia's Highway One Case, www.accountabilityproject.org/downloads/Lessons $\% 20$ from $\% 20$
HW1.doc ґ(accessed on 20-04-2013).

Rao, C.H Hanumantha, 2009; Inclusive Growth-Recent Experience and Challenges Ahead, Economic and Political Weekly, vol. 44, No. 13, http://www.jstor.org/stable/40278655 (accessed on 27-04-2013).

Stanley, Jason; Development-induced Displacement and Resettlement,

http://www.forcedmigration.org/research-resources/expert-guides/ development-induced-displacement-and-resettlement/fmo022.pdf (accessed on 22-04-2013).

The Draft National Land Acquisition and Rehabilitation \& Resettlement Bill, 2011, Ministry of Rural Development, Government of India, July' 2011

http://rural.nic.in/sites/downloads/policies/Final.pdf (accessed on 24-04-2013).

Villalba, Clara Sandoval, 2009; Rehabilitation as a Form of Reparation under International Law, The Redress Trust,http://www.redress.org/downloads/publications/The\%20righ t\%20to\%20rehabilitation.pdf (accessed on 22-04-2013).

Wehrwein, G.S, 1937; An Appraisal of Resettlement, Journal of Farm Economics, vol. 19, No. 1, http://www.jstor.org/stable/1230868 (accessed on 27-04-2013). 